\title{
KORELASI ANTARA STATUS METASTATIK KELENJAR GETAH BENING AKSILA DENGAN EKSPRESI CD44 DAN CXCR4 PADA KARSINOMA PAYUDARA
}

\author{
Heru Fajar Trianto*凶${ }^{\star 凶}$ Endang Joewarini*, Alphania Rahniayu*
}

\begin{abstract}
Abstrak
Karsinoma payudara merupakan salah satu keganasan terbanyak yang menyerang wanita di dunia. Salah satu faktor prognosis karsinoma payudara adalah metastasis pada kelenjar getah bening aksila. CD44 merupakan protein transmembran dan penanda sel punca kanker yang memiliki pengaruh pada pertumbuhan tumor, metastasis, dan rekurensi. CXCR4 merupakan reseptor kemokin yang terekspresi pada beberapa sel tumor salah satunya karsinoma payudara. Penelitian ini bertujuan membuktikan adanya korelasi antara status metastatik kelenjar getah bening aksila dengan ekspresi CD44 dan CXCR4 pada karsinoma payudara. Sebanyak 46 sampel blok parafin pasien karsinoma payudara diperoleh dari Instalasi Patologi Anatomik RSUD Dr.Soetomo Surabaya periode Januari- Desember 2017. Blok parafin dipotong dan dilakukan pulasan immunohistokimia dengan antibodi monoklonal CD44 dan CXCR4. Ekspresi CD44 dan CXCR4 dinilai menggunakan skor imunoreaktif (Immunoreactive score (IRS)). Hasil menunjukkan ekspresi CD44 dan CXCR lebih kuat pada karsinoma payudara dengan metastasis kelenjar getah bening aksila dibandingkan tanpa metastasis kelenjar getah bening aksila $(p=0,001$ dan $p=0,005)$. Terdapat korelasi positif yang signifikan antara status metastatik kelenjar getah bening aksila dengan ekspresi CD44 dan CXCR4 ( $p=0,001$ dan $p=0,004)$. Kesimpulannya adalah terdapat korelasi yang signifikan antara ekspresi CD44 dan CXCR4 dengan kejadian metastasis kelenjar getah bening pada karsinoma payudara. Hal ini menunjukkan bahwa CD44 dan CXCR4 memiliki peran penting dalam kejadian metastasis kelenjar getah bening pada karsinoma payudara.
\end{abstract}

Kata kunci: CD44, CXCR4, karsinoma payudara, status metastatik kelenjar getah bening aksila

\section{CORRELATION BETWEEN AXILLARY LYMPH NODES METASTATIC STATUS WITH CD44 AND CXCR4 EXPRESSIONS IN BREAST CARCINOMA}

\begin{abstract}
Breast carcinoma is one of the most prevalent malignancies in women worldwide. The presence of axillary lymph node metastases is an important prognostic indicator in breast carcinoma. CD44 is a transmembrane protein and a cancer stem cell biomarker that plays a role in tumor proliferation, metastasis, and recurrence. CXCR4 is a chemokine receptor, highly expressed in tumor cells including breast carcinoma cell, and is associated with tumor proliferation, angiogenesis, and metastasis. The aim of this study was to evaluate the correlation of axillary lymph nodes metastatic status with CD44 and CXCR4 expressions in breast carcinoma. This study included 46 paraffin blocks of patients diagnosed as breast carcinoma during January-December 2017 in Anatomical Pathology Laboratory of Dr. Soetomo Hospital. The paraffin blocks were sectioned and stained with immunohistochemistry for CD44 and CXCR4. Expressions of CD44 and CXCR4 were examined with Immunoreactive score (IRS). Expression of CD44 and CXCR4 more intense in breast carcinoma with lymph nodes metastasis than in breast carcinoma without lymph nodes metastasis $(p$ $=0.001$ and $p=0.005$, respectively). There was a significant positive correlation between axillary lymph nodes metastatic status with CD44 and CXCR4 expressions $(p=0.001$ and $p=0.004$, respectively). This study showed expression of CD44 and CXCR4 were significantly correlated with lymph nodes metastasis in breast carcinoma. Our data suggest that CD44 and CXCR4 might be particularly important in facilitating lymph nodes metastasis in breast carcinoma.
\end{abstract}

Keywords: CD44, CXCR4, breast carcinoma, axillary lymph nodes metastatic status *Departemen Patologi Anatomik, Fakultas Kedokteran, Universitas Airlangga Surabaya

$凶$ E-mail: dr.fajr13@gmail.com 


\section{Pendahuluan}

Karsinoma payudara merupakan salah satu keganasan terbanyak pada wanita. Jumlah kasus baru karsinoma payudara di seluruh dunia berkisar 1,7 juta kasus dan jumlah kematian yang diakibatkan oleh karsinoma payudara adalah 560.000 jiwa pada setiap tahunnya. ${ }^{1,2}$ Pusdatin Kementerian Kesehatan Republik Indonesia menunjukkan angka prevalensi kanker payudara di Indonesia adalah sebesar 0,5\% dan menduduki peringkat kedua keganasaan terbanyak pada wanita setelah kanker serviks. Estimasi jumlah penderita kanker payudara di Indonesia pada tahun 2013 sebesar 61.682 jiwa. $^{3}$

Angka harapan hidup pasien karsinoma payudara tergantung pada beberapa faktor prognosis antara lain ukuran tumor, derajat keganasan, invasi pembuluh darah, status estrogen receptor (ER) dan human epidermal growth factor receptor 2 (HER2), serta status metastasis pada kelenjar getah bening. Angka harapan hidup penderita akan turun dari $90 \%$ menjadi $20 \%$ apabila ditemukan metastasis sel tumor pada kelenjar getah bening. Status metastasis sel tumor pada kelenjar getah bening juga berkaitan dengan angka kematian penderita karsinoma payudara. ${ }^{4-6}$

Berbagai faktor ikut terlibat pada kemampuan metastasis sel tumor karsinoma payudara, salah satunya adalah peran sel punca kanker dan lingkungan sekitar tumor. Salah satu penanda sel punca kanker adalah cluster of differentiation 44 (CD44) yang merupakan protein transmembran dan bagian dari molekul adesi sel yang ikut berperan pada komunikasi antar sel serta interaksi dengan matriks ekstraseluler. ${ }^{7}$ Berbagai penelitian menunjukkan sel tumor karsinoma payudara mengekspresikan CD44 dan memiliki kaitan erat dengan kemampuan proliferasi, self renewal dan metastasis dari sel tumor tersebut.1,8,9
Kemampuan sel tumor yang mengekspresikan $C D 44$ untuk bermetastasis dipengaruhi oleh lingkungan mikro di sekitar tumor antara lain sel stromal, matriks ekstraseluler, sel penyusun pembuluh darah, sel imun, dan salah satunya adalah molekul kemokin. ${ }^{10}$ Kemokin yang berperan pada kemampuan migrasi sel tumor adalah $\mathrm{C}-\mathrm{X}-\mathrm{C}$ motif chemokine 12 (CXCL12) yang memiliki reseptor spesifik yaitu $C-X-C$ chemokine receptor 4 (CXCR4) yang terekspresi pada membran sel tumor. Ikatan antara CXCR4 dan CXCL12 akan mengaktifkan mitogen activated protein kinase (MAPK) yang akan meningkatkan kemampuan migrasi sel tumor dan menginduksi angiogenesis.., 11

Pada saat ini belum banyak penelitian yang meneliti mengenai hubungan antara ekspresi CD44 dan CXCR4 dengan status metastatik kelenjar getah bening aksila pada karsinoma payudara menggunakan metode imunohistokimia yang merupakan salah satu metode yang mudah diterapkan.

Penelitian ini bertujuan untuk mengetahui ekspresi CD44 dan CXCR4 sebagai penanda prognosis pada penderita karsinoma payudara yang dikaitkan dengan kejadian metastasis sel tumor pada kelenjar getah bening aksila.

\section{Bahan dan Metode}

\section{Rancangan dan Sampel Penelitian}

Rancangan penelitian yang digunakan adalah analitik observasional dengan pendekatan potong lintang. Sampel penelitian terdiri dari 46 blok parafin penderita karsinoma payudara yang telah dilakukan modified radical mastectomy dengan diagnosis histopatologi sebagai invasive carcinoma of no special type pada Januari hingga Desember 2017 di Instalasi Patologi Anatomi RSUD Dr. Soetomo Surabaya. Sampel dibagi ke dalam dua kelompok yang terdiri dari 23 blok parafin karsinoma payudara dengan metastasis kelenjar getah 
bening aksila dan 23 blok parafin karsinoma payudara tanpa metastasis kelenjar getah bening aksila. Penelitian ini telah mendapatkan persetujuan dari Komite Etik Penelitian Kesehatan RSUD Dr. Soetomo Surabaya (0608/KEPK/IX/2018).

\section{Prosedur Pembuatan Blok Parafin}

Jaringan tumor payudara yang telah difiksasi dengan neutral buffered formalin (NBF) 10\% kemudian dipotong dengan ketebalan $4 \mathrm{~mm}$ dan diletakkan dalam kaset. Jaringan kemudian dimasukkan dalam mesin processing jaringan yang secara berurutan terdiri dari larutan NBF $10 \%$, alkohol $70 \%$, $80 \%, 90 \%$, dan $96 \%$, xylene, dan parafin cair. Jaringan kemudian dicetak (embedding) menggunakan larutan parafin cair pada blok parafin.

\section{Prosedur Imunohistokimia}

Ekspresi CD44 dan CXCR4 pada sampel diamati menggunakan pulasan imunohistokimia. Blok parafin dipotong $4 \mu \mathrm{m}$, dilakukan deparafinisasi, dan rehidrasi dengan alkohol 96\%, 90\%, dan $80 \%$. Dihangatkan dengan buffer citrate $\mathrm{pH} 6$ selama 20 menit dalam microwave. Sampel kemudian diteteskan antibodi primer yaitu CD44 (sc-7297, Santa Cruz Biotechnology, Inc.) dengan dilusi 1:200 dan antibodi CXCR4 (sc-53534, Santa Cruz Biotechnology, Inc.) dengan dilusi 1:200 pada suhu $4{ }^{\circ} \mathrm{C}$ overnight. Sampel selanjutnya diteteskan antibodi sekunder dan diinkubasi selama 20 menit, selanjutnya diberikan diaminbenzidine (DAB) dan dilakukan counterstain dengan meyer hematoksilin.

\section{Analisis Pewarnaan Imunohistokimia}

Ekspresi CD44 dan CXCR4 dinilai menggunakan immunoreactive score (IRS) secara semikuantitatif yang merupakan perkalian dari persentase sel tumor yang terpulas (A) dan intensitas pewarnaan (B). Persentase dikelompokkan sebagai berikut: skor 0 = tidak ada sel tumor yang terpulas, skor $1=<10 \%$ sel tumor yang terpulas, skor 2 $=10-50 \%$ sel tumor yang terpulas, skor $3=$ $51-80 \%$ sel tumor yang terpulas, dan skor $4=$ $>80 \%$ sel tumor yang terpulas. Intensitas dibagi menjadi: skor $0=$ tidak terwarna, skor $1=$ intensitas ringan, skor $2=$ intensitas sedang, dan skor $3=$ intensitas kuat. IRS (AXB) dibagi menjadi 4 kelompok yaitu negatif (skor 0-1), lemah (skor 2-3), sedang (skor 4-8), dan kuat (skor 9-12). Ekspresi CD44 diamati pada membran dan atau sitoplasma sel tumor. Ekspresi CXCR4 diamati pada membran, sitoplasma, dan atau inti sel tumor. Pengamatan ekspresi CD44 dan CXCR4 dilakukan menggunakan mikroskop cahaya binokular pada seluruh lapang pandang.

\section{Analisis Statistik}

Perbedaan ekspresi CD44 dan CXCR4 pada kedua kelompok dianalisis dengan uji $\mathrm{T}$ tidak berpasangan atau uji Mann Whitney. Hasil uji dikatakan berbeda bermakna bila didapatkan nilai $p<0,05$. Korelasi antara status metastatik kelenjar getah bening aksila dengan ekspresi CD44 dan CXCR4 dilakukan uji korelasi Spearman. Korelasi antara ekspresi CD44 dengan ekspresi CXCR4 dilakukan uji korelasi Spearman. Hasil uji dikatakan memiliki korelasi yang signifikan bila didapatkan nilai $p<0,05$.

\section{Hasil}

\section{Ekspresi CD44}

Ekspresi CD44 pada penelitian ini terpulas pada membran dan atau sitoplasma sel tumor (Gambar 1). Hasil penelitian ini menunjukkan bahwa ekspresi CD44 dengan skor IRS kuat lebih banyak terdapat pada karsinoma payudara dengan metastasis kelenjar getah bening aksila yaitu sebesar $78,3 \%$. Hasil uji $T$ tidak berpasangan menunjukkan bahwa terdapat perbedaan yang signifikan ekspresi CD44 yang dinilai 
menggunakan skor IRS pada karsinoma payudara dengan dan tanpa metastasis kelenjar getah bening aksila $(p=0,001)$ (Tabel 1).

Hasil uji korelasi Spearman menunjukkan hubungan yang bermakna antara status metastatik kelenjar getah bening aksila dengan ekspresi CD44 ( $p=$ 0,001 ) dengan nilai koefisien korelasi yang positif sebesar 0,630. Hasil tersebut menunjukkan bahwa semakin tinggi ekspresi CD44 maka sejalan dengan peningkatan status metastasis kelenjar getah bening aksila (Tabel 2).

\section{Ekspresi CXCR4}

Ekspresi protein CXCR4 pada penelitian ini terpulas pada membran, sitoplasma, dan atau inti sel tumor. Pada tumor dengan ekspresi CXCR4 kuat terdapat variasi lokasi ekspresi protein, yaitu terdapat sel tumor dengan ekspresi CXCR4 pada sitoplasma dan inti dan terdapat ekspresi CXCR4 yang terpulas hanya pada sitoplasma (Gambar 2).

Hasil penelitian ini menunjukkan bahwa karsinoma payudara dengan metastasis kelenjar getah bening aksila memiliki ekspresi CXCR4 dengan skor IRS kuat yang lebih banyak yaitu sebesar $60,9 \%$. Hasil uji beda Mann Whitney menunjukkan bahwa terdapat perbedaan yang signifikan antara ekspresi CXCR4 pada karsinoma payudara dengan dan tanpa metastasis kelenjar getah bening aksila $(p=0,005)$ (Tabel 3 ).

Terdapat hubungan yang bermakna antara status metastatik kelenjar getah bening aksila dengan ekspresi CXCR4 $(p=$ $0,004)$ dengan nilai koefisisen korelasi yang positif sebesar 0,421 (Tabel 4).

Hubungan antara Espresi CD44 dengan
Ekspresi CXCR4
Hasil uji korelasi Spearman
menunjukkan hubungan yang bermakna
antara ekspresi CD44 dengan ekspresi
CXCR4 ( $p=0,002$ ) dengan nilai koefisien
korelasi yang positif sebesar 0,448 . Hasil
tersebut menunjukkan bahwa semakin tinggi
ekspresi CD44 maka sejalan dengan
peningkatan ekspresi CXCR4.

Tabel 1. Ekspresi CD44 pada status metastatik kelenjar getah bening aksila karsinoma payudara.

\begin{tabular}{lcccc}
\hline Ekspresi CD44 & Kategori & Tanpa Metastasis & Dengan Metastasis & $p$ \\
\hline Persentase & Tidak ada sel & $0(0 \%)$ & $0(0 \%)$ & \\
& yang positif & & & \\
& $<10 \%$ & $0(0 \%)$ & $0(0 \%)$ & \\
& $10-50 \%$ & $6(26,1 \%)$ & $0(0 \%)$ & \\
Intensitas & $51-80 \%$ & $15(65,2 \%)$ & $15(65,2 \%)$ & \\
& $>80 \%$ & $2(8,7 \%)$ & $8(34,8 \%)$ & \\
& Tidak terwarna & $0(0 \%)$ & $0(0 \%)$ & \\
& Intensitas ringan & $6(26,1 \%)$ & $0(0 \%)$ & \\
& Intensitas & $13(56,5 \%)$ & $5(21,7 \%)$ & \\
\multirow{5}{*}{ Skor IRS } & sedang & $4(17,4 \%)$ & $18(78,3 \%)$ & \\
& Intensitas kuat & & & \\
& Negatif & $0(0 \%)$ & $0(0 \%)$ & 001 \\
& Lemah & $6(26,1 \%)$ & $0(0 \%)$ & \\
& Sedang & $13(56,5 \%)$ & $5(21,7 \%)$ & \\
& Kuat & $4(17,4 \%)$ & $18(78,3 \%)$ & \\
\hline
\end{tabular}


Tabel 2. Hasil uji korelasi Spearman ekspresi CD44 dengan status metastatik kelenjar getah bening aksila.

\begin{tabular}{|c|c|c|}
\hline & & Ekspresi CD44 \\
\hline Status metastatik & $r$ & 0,630 \\
\hline kelenjar getah bening & $p$ & 0,001 \\
\hline aksila & $\mathrm{n}$ & 46 \\
\hline
\end{tabular}

Tabel 3. Ekspresi CXCR4 pada status metastatik kelenjar getah bening aksila karsinoma payudara.

\begin{tabular}{lcccc}
\hline Ekspresi CD44 & Kategori & $\begin{array}{c}\text { Tanpa } \\
\text { Metastasis }\end{array}$ & $\begin{array}{c}\text { Dengan } \\
\text { Metastasis }\end{array}$ & $\mathrm{p}$ \\
\hline Persentase & Tidak ada sel yang & $0(0 \%)$ & $0(0 \%)$ & \\
& positif & & & \\
& $<10 \%$ & $0(0 \%)$ & $0(0 \%)$ & \\
& $10-50 \%$ & $2(8,7 \%)$ & $1(4,3 \%)$ & \\
Intensitas & $51-80 \%$ & $17(73,9 \%)$ & $10(43,5 \%)$ & \\
& $>80 \%$ & $4(17,4 \%)$ & $12(52,2 \%)$ & \\
& Tidak terwarna & $0(0 \%)$ & $0(0 \%)$ & \\
Skor IRS & Intensitas ringan & $7(30,4 \%)$ & $2(8,7 \%)$ & \\
& Intensitas sedang & $9(39,1 \%)$ & $7(30,4 \%)$ & \\
& Intensitas kuat & $7(32,4 \%)$ & $14(60,9 \%)$ & \multirow{2}{*}{0,005} \\
& Negatif & $0(0 \%)$ & $0(0 \%)$ & \\
& Lemah & $6(26,1 \%)$ & $2(8,7 \%)$ & \\
& Sedang & $13(56,5 \%)$ & $7(30,4 \%)$ & \\
\hline
\end{tabular}

Tabel 4. Hasil uji korelasi Spearman ekspresi CXCR4 dengan status metastatik kelenjar getah bening aksila.

\begin{tabular}{|c|c|c|}
\hline & & Ekspresi CXCR4 \\
\hline metastatik & $r$ & 0,421 \\
\hline kelenjar getah bening & $p$ & 0,004 \\
\hline aksila & $\mathrm{n}$ & 46 \\
\hline
\end{tabular}



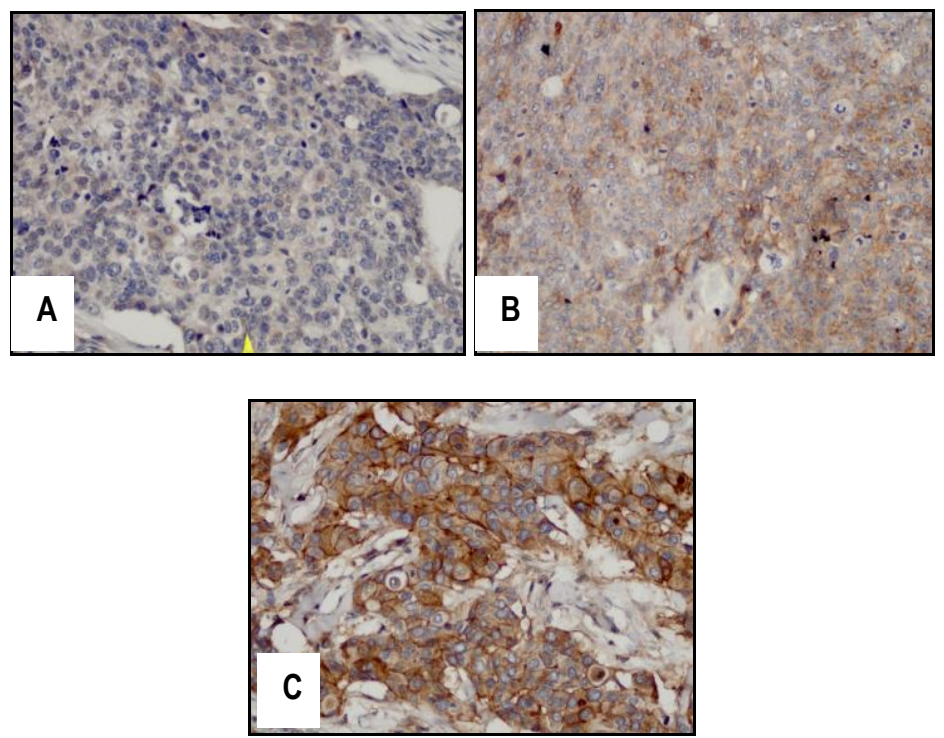

Gambar 1. Ekspresi CD44 dengan pewarnaan imunohistokimia.

Keterangan: CD44 terpulas coklat pada membran dan atau sitoplasma sel tumor. (A) intensitas ringan, (B) intensitas sedang, (C) intensitas kuat (400x).
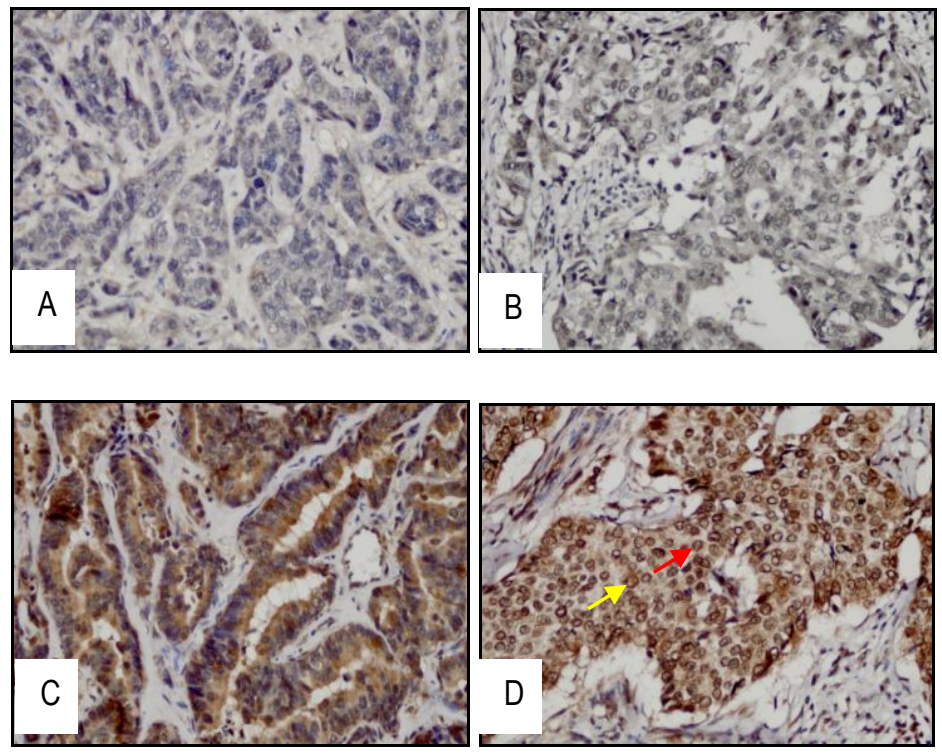

Gambar 2. Ekspresi CXCR4 dengan pewarnaan imunohistokimia.

Keterangan: CXCR4 terpulas coklat pada membran, sitoplasma, dan atau inti sel tumor (panah merah), (A) intensitas ringan, (B) intensitas sedang, (C) intensitas kuat terpulas pada membran dan sitoplasma, (D) intensitas kuat terpulas pada membran, sitoplasma, dan inti (panah kuning) $(400 x)$.

\section{Pembahasan}

Ekspresi CD44 dan Status Metastatik Kelenjar Getah Bening Aksila

Hasil penelitian ini menunjukkan bahwa ekspresi CD44 terpulas lebih kuat pada karsinoma payudara dengan metastasis kelenjar getah bening aksila dan terdapat korelasi yang positif yang menunjukkan bahwa semakin tinggi ekspresi CD44 sejalan dengan terjadinya metastasis kelenjar getah bening aksila pada karsinoma payudara.

Hasil penelitian ini sejalan dengan penelitian yang dilakukan oleh Ma dan Jiang 
(2013) yang menunjukkan korelasi yang bermakna antara ko-ekspresi CD44 dan Ezrin dengan status metastasis kelenjar getah bening pada karsinoma payudara. ${ }^{12}$ Penelitian pada kultur sel tumor payudara menunjukkan bahwa sel tumor dengan CD44 yang positif memiliki kemampuan invasi yang lebih tinggi. Kemampuan invasi tersebut memiliki hubungan erat dengan metastasis. ${ }^{13}$ Penelitian lain pada karsinoma nasofaring menunjukkan bahwa ekspresi mRNA CD44 lebih tinggi pada karsinoma nasofaring dengan metastasis kelenjar getah bening dibandingkan tanpa metastasis kelenjar getah bening. ${ }^{14}$

Protein CD44 merupakan protein transmembran yang dapat terekspresi pada berbagai kanker salah satunya adalah sel tumor payudara. CD44 memiliki ligan spesifik berupa asam hyaluronan (HA). Ikatan antara CD44 dengan HA akan memicu berbagai sinyal intraseluler yang dapat mempengaruhi pertumbuhan, kemampuan migrasi, dan kemampuan bertahan dari sel tumor. Ikatan tersebut akan mengaktivasi reseptor tirosin kinase (ErbB2 dan EGFR) dan reseptor transforming growth factor- $\beta$ (TGF- $\beta$ ) dan non reseptor kinase (Src family) atau Ras family GTPase. Aktivasi reseptor-reseptor tersebut dapat mengaktivasi beberapa sinyal intraseluler antara lain MAPK dan $\mathrm{PI} 3$ kinase/akt. CD44 juga mampu mempengaruhi faktor pro dan antiapoptosis seperti inaktivasi protein proapoptosis Bcl-2associated death promoter (BAD), Bax, caspase 3,caspase 8 , dan caspase 9 serta meningkatkan aktivasi protein antiapoptosis seperti Bcl-2 dan Bcl-xL. Beberapa mekanisme di atas dapat menyebabkan sel tumor mampu berproliferasi, migrasi, dan kemoresisten. ${ }^{15,16}$

Protein CD44 juga mampu mengaktifkan mekanisme epithelial-mesenchymal-transition (EMT) yang menyebabkan sel tumor mampu bermetastasis. Penanda mekanisme EMT pada kanker adalah penurunan ekspresi E- cadherin yang merupakan protein pengikat antar sel dan translokasi $\beta$ catenin. Mekanisme EMT tersebut mengakibatkan peningkatkan kemampuan motilitas dari sel tumor. Interaksi antara CD44 dengan HA juga dapat mengakibatkan degradasi kolagen yang merupakan komponen matriks ekstraseluler. CD44 juga terkait dengan protein matrix metalloprotease (MMP) yang merupakan protein yang dapat mendegradasi membran basal sehingga dapat menyebabkan migrasi dari sel tumor., 711,16

Peran CD44 pada progesifitas sel tumor dipengaruhi oleh lingkungan mikro di sekitar tumor antara lain sel imun, fibroblas, sel endotel vaskular, komponen matriks ekstraseluler, serta berbagai sitokin. Berbagai sitokin yang mempengaruhi kinerja CD44 antara lain IL-8, G-CSF, yang berperan pada proliferasi sel tumor, angiogenesis, dan metastasis, TGF- $\beta$ yang ikut dalam mekanisme EMT yang berpengaruh pada invasi dan metastasis sel tumor, serta molekul kemokin yang berperan sebagai kemoatraktan. Salah satu molekul kemokin yang mempengaruhi kinerja CD44 adalah CXCL12 yang memiliki reseptor spesifik yaitu CXCR4. $10,17,18$

Ekspresi CXCR4 dan Status Metastatik Kelenjar Getah Bening Aksila

Hasil penelitian ini menunjukkan bahwa karsinoma payudara dengan metastasis kelenjar getah bening aksila memiliki ekpresi CXCR4 yang lebih kuat dibandingkan dengan karsinoma payudara tanpa metastasis kelenjar getah bening aksila $(p<0,05)$. Uji korelasi Spearman menunjukkan bahwa terdapat hubungan yang bermakna antara ekspresi CXCR4 dengan kejadian metastasis kelenjar getah bening aksila pada karsinoma payudara $(p<0,05)$.

Hasil penelitian ini sejalan dengan beberapa penelitian yang telah dilakukan sebelumnya. Penelitian yang dilakukan oleh Dayer et al. (2018), yang meneliti ekspresi 
CXCR4 menggunakan metode quantitative real-time polymerase chain reaction (Q-RTPCR) pada jaringan tumor dari penderita karsinoma payudara invasif, menunjukkan hasil bahwa ekspresi CXCR4 lebih tinggi pada karsinoma payudara dengan metastasis kelenjar getah bening. ${ }^{19}$ Penelitian lain yang dilakukan oleh Cabioglu et al. (2005), pada jaringan kanker payudara menggunakan metode imunohistokimia, menunjukkan bahwa sel tumor kanker payudara dengan metastasis kelenjar getah bening mengekspresikan CXCR4 lebih kuat dibandingkan tanpa metastasis kelenjar getah bening. Penelitian tersebut juga meneliti sensitivitas dan spesifitas CXCR4 dalam memprediksi metastasis kelenjar getah bening yang didapatkan hasil sensitivitas CXCR4 sebesar $11 \%$ dan spesifitas sebesar $95 \% .{ }^{20}$

Reseptor kemokin CXCR4 merupakan protein transmembran yang termasuk dalam kelompok reseptor protein $G$ berpasangan. CXCR4 dapat terekpresi pada jaringan normal antara lain sel imun yaitu limfosit, netrofil, makrofag, dan sel endotel serta membran sel tumor, dan akan berikatan dengan ligan yang spesifik yaitu CXCL12. Ikatan antara CXCR4 dengan CXCL12 akan mengaktifkan berbagai sinyal transduksi intraseluler yang dapat mempengaruhi kemampuan invasi dan metastasis dari sel tumor 2, 21-23

Aktivasi protein CXCR4 akan mengaktifkan berbagai jalur sinyal intraseluler. CXCR4 yang teraktivasi akan terpecah menjadi sub unit a dan sub unit $\beta \gamma$. Sub unit $\beta y$ akan memicu aktivasi sinyal jalur phosphoinositide-3 kinase (PI3K)/AKT yang akan memicu NF-k $\beta$ sehingga meningkatkan proliferasi sel tumor. Aktivasi CXCR4 melalui sub unit $\beta y$ juga menginduksi protein Ras yang akan mengaktivasi RAF. Selanjutnya mengaktivasi extracellular signal-regulated kinase (ERK 1/2) yang akan meningkatkan proliferasi dan kemampuan migrasi sel tumor.
Sub unit a akan menginduksi phospholipase$c$ (PLC) yang akan membuat phosphatydilinositol 4,5-biphosphate (PIP2) menghasilkan second messenger yaitu diacylglycerol (DAG) dan inositol triphosphate (IP3). IP3 akan meningkatkan pengeluaran kalsium intraseluler dari retikulum endoplasma, yang bersama dengan DAG akan mengaktifkan protein kinase $C$ (PKC). Aktivasi PKC akan meningkatkan kemampuan migrasi sel tumor. ${ }^{18,24}$

Protein CXCR4 dapat meningkatkan kejadian metastasis sel tumor melalui proses angiogenesis. Ikatan antara CXCR4 dan CXCL12 akan meningkatkan aktivasi sel progenitor endotelial untuk datang ke lingkungan sekitar sel tumor dan membentuk pembuluh darah baru. CXCR4 dikaitkan dengan ekspresi VEGF dan platelet derived growth factor $\mathrm{D}$ (PDGF-D) yang dihubungkan dengan pembentukan dan stabilisasi pembuluh darah baru di sekitar tumor. Pembentukan pembuluh darah baru di sekitar tumor akan meningkatkan kejadian metastasis dari sel tumor. ${ }^{21,23,24}$ CXCR4 juga dapat mempengaruhi sistem imun di sekitar sel tumor. Protein CXCR4 akan menarik sel dendritik untuk datang di lingkungan sekitar tumor. Sel dendritik memiliki kemampuan untuk mensupresi imunitas antitumor dengan cara inaktivasi dari sel limfosit T sitotoksik. ${ }^{18}$

Pengamatan pada penelitian ini didapatkan ekspresi CXCR4 terpulas positif pada membran dan atau sitoplasma dan atau inti sel tumor. Pada sel tumor dengan ekspresi CXCR4 kuat terdapat variasi lokasi dari ekspresi CXCR4, yaitu terdapat sel tumor dengan ekspresi CXCR4 pada sitoplasma dan inti dan terdapat ekspresi CXCR4 yang terpulas hanya pada sitoplasma.

Beberapa penelitian melakukan penelitian mengenai lokasi ekepresi CXCR4 pada sel tumor dan dikaitkan dengan parameter klinikopatologi dan angka kesembuhan pada berbagai macam kanker. Hasil penelitian Cabioglu et al. (2005) dan 
Yasuoka et al. (2008), menunjukkan bahwa ekspresi CXCR4 pada sitoplasma sel tumor memiliki hubungan yang bermakna dengan kejadian metastasis kelenjar getah bening aksila pada karsinoma payudara, sedangkan ekspresi CXCR4 pada inti sel tumor tidak memiliki hubungan yang bermakna dengan kejadian metastasis kelenjar getah bening. ${ }^{20,25}$ Penelitian yang dilakukan oleh Salvucci et al (2006) pada jaringan kanker payudara menunjukkan bahwa sel tumor dengan ekspresi CXCR4 pada inti terkait dengan grade yang tinggi, stadium yang lebih lanjut dan angka harapan hidup yang lebih rendah. ${ }^{26}$ Penelitian lain yang dilakukan oleh Speetjens et al (2009) pada penderita kanker kolorektal menunjukkan bahwa tumor dengan ekspresi CXCR4 pada inti memiliki prognosis yang lebih buruk yang dikaitkan dengan angka harapan hidup dan stadium tumor. ${ }^{27}$

Mekanisme ekspresi CXCR4 pada inti sel tumor masih belum jelas. Beberapa peneliti menyatakan bahwa ikatan antara CXCR4 dengan CXCL12 dapat menginduksi terjadinya translokasi CXCR4 ke dalam sitoplasma dan inti sel. Translokasi CXCR4 ke dalam inti sel dapat mengaktifkan faktor transkrispsi yang terletak di inti. ${ }^{27}$ Peneliti yang lain menyatakan bahwa terdapat endosom yang memfasilitasi translokasi CXCR4 melalui clathrin-coated pits dan membutuhkan molekul Hsc73. ${ }^{28}$

\section{Hubungan antara Ekspresi CD44 dengan Ekspresi CXCR4}

Hasil penelitian ini menunjukkan bahwa terdapat korelasi antara ekspresi CD44 dengan ekspresi CXCR4 pada status metastatik kelenjar getah bening aksila karsinoma payudara $(p<0,005)$.

Hasil penelitian ini sejalan dengan beberapa penelitian yang telah dilakukan sebelumnya. Penelitian yang dilakukan oleh Sheridan et al. (2006), yang menggunakan kultur sel tumor kanker payudara pada hewan coba, menunjukkan bahwa sel tumor yang mengekspresikan CD44 juga mengekspresikan CXCR4 yang terkait dengan peningkatan invasi sel tumor tersebut, meskipun hasilnya tidak bermakna secara statistik. ${ }^{13}$ Penelitian lain yang dilakukan oleh Huang et al. (2010), menunjukkan bahwa pemberian AMD3100 sebagai antagonis dari CXCR4 pada kultur sel tumor kanker payudara dapat menurunkan ekspresi CD44 pada sel tersebut. ${ }^{1}$

Beberapa penelitian pada kanker lainnya juga menunjukkan hubungan antara CD44 dengan CXCR4. Penelitian yang dilakukan oleh Ma et al. (2012), menunjukkan bahwa ekspresi CD44 dan CXCR4 yang tinggi terkait dengan osteosarkoma yang lebih agresif. ${ }^{29}$ Penelitian yang dilakukan oleh Bao et al. (2011), menunjukkan bahwa kultur sel kanker gaster yang telah dilakukan knockdown CD44 secara signifikan berakibat pada turunnya ekspresi CXCR4. ${ }^{30}$ Pada saat ini belum banyak penelitian terkait korelasi antara ekspresi CD44 dengan ekspresi CXCR4 menggunakan metode imunohistokimia.

Beberapa penelitian menunjukkan hubungan antara CD44 dengan CXCR4 dengan berbagai mekanisme. Penelitian yang dilakukan oleh Bao et al. (2011) dan Ma et al. (2012), menunjukkan bahwa terdapat kaitan antara CD44 dan CXCR4 yang diperantai oleh HER2. CD44 akan mengaktivasi HER2 dan kemudian HER2 akan mengaktivasi CXCR4. Aktivasi CXCR4 akan mengaktifkan berbagai sinyal intraseluler yang berpengaruh pada pertumbuhan dan migrasi sel tumor. Interaksi antara HER2 dan CXCR4 juga akan mempengaruhi berbagai faktor apoptosis. ${ }^{29,30}$

Penelitian yang dilakukan oleh Fuchs et al. (2010), menunjukkan mekanisme lain dalam interaksi CD44 dan CXCR4. Asam hyaluronan $(\mathrm{HA})$ yang merupakan ligan dari CD44 akan mengaktifkan CXCL12 yang merupakan ligan dari CXCR4. Ikatan antara CXCR4 dengan CXCL12 akan mengaktifkan 
berbagai sinyal intraseluler yang berpengaruh pada sel tumor salah satunya adalah fosforilasi ERK. CXCL12 dapat secara langsung mengaktifkan sel endotel untuk pembentukan angiogenesis, namun ikatan antara CXCR4-CXCL12 dapat mempengaruhi produksi VEGF yang juga dapat memicu angiogenesis. ${ }^{10}$

Pada penelitian ini menunjukkan bahwa CD44 dan CXCR4 dapat digunakan sebagai penanda prognosis yang terkait dengan status metastatis sel tumor ke kelenjar getah bening aksila pada penderita karsinoma payudara, yang akan berguna bagi angka harapan hidup pasien. Keterbatasan dalam penelitian ini adalah tidak mengamati berbagai faktor klinikopatologi lainnya seperti ukuran tumor, derajat diferensiasi, status reseptor hormonal, dan berbagai tipe histopatologi.

\section{Kesimpulan}

Didapatkan hubungan yang bermakna antara ekspresi CD44 dan ekspresi CXCR4 dengan kejadian metastasis kelenjar getah bening aksila pada karsinoma payudara. Ekspresi CD44 dan CXCR4 lebih kuat pada karsinoma payudara dengan metastasis kelenjar getah bening aksila.

\section{Saran}

Penelitian lebih lanjut yang mengamati hubungan antara CD44 dan CXCR4 dengan biomarker lain seperti HER2, MMP, dan VEGF yang berperan pada proses metastasis serta penelitian yang mengamati ekspresi CD44 dan CXCR4 dengan parameter klinikopatologi lainnya.

\section{Daftar Pustaka}

1. Huang M, Li Y, Zhang H, Nan F. Breast Cancer Stromal Fibroblasts Promote the Generation of CD44+CD24- Cells Through
SDF-1/CXCR4 Interaction. Journal of Experimental and Clinical Cancer Research. 2010; 29(1): 1-10.

2. Kishima MO, de Oliveira CEC, Banin-Hirata BK, Losi-Guembarovski R, de Oliveira KB, Amarante MK, et al. Immunohistochemical Expression of CXCR4 on Breast Cancer and its Clinical Significance. Analytical Cellular Pathology. 2015; 2015: 1-6.

3. Pusat Data dan Informasi Kesehatan RI. Infodatin. Kementerian Kesehatan RI. (Online). 2015. http://www.depkes.go.id/resources/downlo ad/pusdatin/infodatin/infodatin-kanker.pdf. Diunduh tanggal 7 April 2018.

4. Colditz G, Chia KS. Invasive vreast carcinoma: Introduction and general features. In: Lakhani SR, Ellis IO, Schnitt SJ, Tan PH, de Vijver MJ (Ed). WHO Classification of Tumours of the Breast. $4^{\text {th }}$ edition. Lyon: International Agency for Research on Cancer (IARC). 2012. p.1421.

5. Mukherjee D, Zhao J. The Role of Chemokine Receptor CXCR4 in Breast Cancer Metastasis. American journal of cancer research. 2013; 3(1): 46-57.

6. Sun Y, Mao X, Fan C, Liu C, Guo A, et al. CXCL12-CXCR4 axis promotes the natural selection of breast cancer cell metastasis. Tumor Biology. 2014; 35(8): 7765-7773.

7.Louderbough JMV, Schroeder JA. Understanding the Dual Nature of CD44 in Breast Cancer Progression. Molecular Cancer Research. 2011;9(12): 1573-1586.

8. Basakran NS. CD44 as a Potential Diagnostic Tumor Marker. Saudi Medical Journal. 2015; 36(3): 273-279.

9. Li W, Ma H, Zhang J, Zhu L, Whang C,et al. Unraveling the Roles of CD44/CD24 and ALDH1 as Cancer Stem Cell Markers in Tumorigenesis and Metastasis. Scientific Reports. 2017; 7(1): 1-15.

10. Fuchs K, Hippe A, Schmaus A, Homey B., Sleeman JP, et al. Opposing Effects of 
High-and Low-molecular Weight Hyaluronan on CXCL12-induced CXCR4 Signaling Depend on CD44. Cell Death and Disease. 2013 ;4(10): 1-11.

11. Orian-Rousseau V. CD44 Acts as a Signaling Platform Controlling Tumor Progression and Metastasis. Frontiers in Immunology. 2015; 6(APR): 10-13.

12. Ma $L$, Jiang $T$. Clinical implications of Ezrin and CD44 co-expression on breast cancer. Oncology Reports. 2013; 30: 1899-1905.

13. Sheridan C, Kishimoto $H$, Fuchs RK, Mehrotra S, Bhat-Nakshatri $\mathrm{P}$, et al. CD44 + CD24- breast cancer cells exhibit enhanced invase properties: An early step necessary for metastasis. Breast Cancer Research. 2006; 8(5): 1-13.

14. Sun DY, Yu H, Qiu XB, Li G, Zhang N. Relationships between $\mathrm{CD} 44$, hyaluronic acid expression and lymphatic metastasis and radiosensitivity of nasopharyngeal carcinoma. Biomedical Research. 2016; 27(2): 286-291.

15. Thapa R, Wilson GD. The Importance of CD44 as a Stem Cell Biomarker and Therapeutic Target in Cancer. Stem Cells International. 2016; 2016: 1-15.

16. Chanmee $T$, Ontong $P$, Kimata $K$, Itano N. Key Roles of Hyaluronan and Its CD44 Receptor in the Stemness and Survival of Cancer Stem Cells. Frontiers in Oncology. 2015; 5(180): 1-11.

17. Vira D, Basak SK, Veena MS, Wang MB, Batra RK, et al. Cancer Stem Cells, microRNAs, and Therapeutic Strategies Including Natural Products. Cancer and Metastasis Reviews. 2012; 31(3-4): 733751.

18. Xu C, Zhao H, Chen H, Yao Q. CXCR4 in Breast Cancer: Oncogenic Role And Therapeutic Targeting. Drug Design, Development and Therapy. 2015; 9: 4953-4964.

19. Dayer R, Babashah S, Jamshidi S, Sadeghizadeh M. Upregulation of CXC
Chemokine Receptor 4-CXC Chemokine Ligand 12 Axis in Invasive Breast Carcinoma: A Potent Biomarker Predicting Lymph Node Metastasis. J Can Res Ther. 2018;14: 345-350.

20. Cabioglu N, Yazici MS, Arun B, Broglio $\mathrm{KR}$, Hortobagyi GN, et al. CCR7 and CXCR4 as Novel Biomarkers Predicting Axillary Lymph Node Metastasis in T1 Breast Cancer. Clin Cancer Res. 2005; 11(16): 5686-5693.

21. Hiller D, Chu QD. CXCR4 and Axillary Lymph Nodes: Review of Potential Biomarker for Breast Cancer Metastasis. International Journal of Breast Cancer. 2011; 2011: 1-6.

22. Fischer $T$, Nagel $F$, Jacobs $S$, Stumm $R$, Schulz S. Reassesment of CXCR4 Chemokine Receptor Expression in Human Normal and Neoplastic Tissue Using Novel Rabbit Monoclonal Antibody UMB-2. PIOS ONE. 2008; 3(12): 1-7.

23. Domanska UM, Kruizinga RC, Nagengast WB, Timmer-Bosscha H, Huls G, et al. A Review on CXCR4/CXCL12 Axis in Oncology: No Place to Hide. European Journal of Cancer. 2013; 49(1): 219-230.

24. Cojoc, M., Peitzsch, C., Trautmann, F., Polishchuk, L., Telegeev, G.D., Dubrovska, A. Emerging Targets in Cancer Management: Role of the CXCL12/CXCR4 Axis. Onco Targets and Therapy. 2013;6: 1347-1361.

25. Yasuoka H, Tsujimoto M, Yoshidome K, Nakahara $M$, Kodama $R$, et al. Cytoplasmic CXCR4 Expression in Breast Cancer: Induction by Nitric Oxide and Correlation with Lymph Node Metastasis and Poor Prognosis. BMC Cancer. 2008; 8(340):1-10.

26. Salvucci O, Bouchard A, Baccarelli A, Deschenes J, Sauter G, et al. The Role of CXCR4 Receptor Expression in Breast Cancer: A Large Tissue Microarray Study. Breast Cancer Research and Treatment. 2006; 97(3): 275-283. 
27. Speetjens FM, Liefers GJ, Korbee CJ, Mesker WE, van de Velde CJH, et al. Nuclear Localization of CXCR4 Determines Prognosis for Colorectal Cancer Patients. Cancer Microenvironment. 2009; 2: 1-7.

28. Wang L, Wang Z, Yang B, Yang Q., Wang $L$, et al. CXCR4 Nuclear Localization Follows Bindings of its Ligand SDF-1 and Occurs in Metastatic but Not Primary Renal Cell Carcinoma. Oncology Reports. 2009; 22: 1333-1339.

29. Ma $Q$, Zhou $Y, M a ~ B$, Chen $X$, Wen $Y$, et al. The Clinical Value of CXCR4, HER2 and CD44 in Human Osteosarcoma: A Pilot Study. Oncology Letters. 2012; 3(4): 797-801.

30. Bao W, Fu H-J, Xie Q-S, Wang L, Zhang $\mathrm{R}$, et al. HER2 Interacts with CD44 to Upregulate CXCR4 via Epigenetic Silencing of microRNA-139 in Gastric Cancer Cells. Gastroenterology. 2011; 141: 2076-2087. 